\title{
Synthesis of a BINOL Derivative Fluorescent Sensor S-N,N'-(2,2'-dimethoxy-[1,1'-binaphthalene] -6,6'-diyl)bis (ethane-1,2-diamine)
}

\author{
Chuan-Chuan XU' ${ }^{1, a}$, Li-Yi MO ${ }^{1, b}$ and Xiao-Xia SUN ${ }^{1, c^{*}}$ \\ ${ }^{1}$ Jiangxi Key Laboratory of Organic Chemistry, Jiangxi Science and Technology Normal University, \\ Nanchang 330013, People's Republic of China \\ axuchuanchuan@126.com; bmoliyi@163.com; c; 'sunxiaoxia77@126.com; \\ ${ }^{*}$ Corresponding author
}

Keyword: fluorescent probe, BINOL, ion recognition.

Abstract. Optically active fluorescent sensor containing a 1,1'-binaphthyl core and N,N'-diamine was synthesized and characterized by NMR spectroscopy. $S$-N1,N1'-(2,2'-dimethoxy-[1,1'-binaphthalene]-6,6'-diyl)bis (ethane-1,2-diamine) was synthesized by coupling reaction with $\mathrm{Pd}(\mathrm{dppf}) \mathrm{Cl}_{2}$ and $\mathrm{Cu}($ phen $) \mathrm{Cl}_{2}$.

\section{Introduction}

Fluorescent probe is a kind of molecules which have character fluorescent from ultraviolet to near-infrared light area, and fluorescent property varies in some degree with the change of the environment. As the advantages of highly sensitivity, highly selectivity and convenient operation, fluorescent probe is widely used for detecting of cation, anion and neutral molecule [1-6]. Optically active fluorescent sensors are also having increased attentions because they can provide real time analysis for the enantiomeric composition of chiral compounds and enhance the sensitivity in the detection of chiral substrates [7-15].1-(2-hydroxynaphthalen-1-yl)naphthalen-2-ol, popularly known as BINOL, has the phenomenon of atropisomerism, one stereoisomerism finding in systems where the rotation around a single bond which is restricted to yield different stereoisomers. Among the enantioselective fluorescent sensors synthesized, which based on chiral structure of 1,10-bi-2-naphthol (BINOL) have been highly investigated, and a few highly enantioselective fluores-cent sensors have been found for the recognition of R-hydroxycarboxylic acids, chiral amines, amino acids and amino alcohols.

Because BINOL and its derivatives have the obvious different characteristic of special rigid structure, easy modification and the size of angle between two naphthalene ring freely adjusted, they are usually used to design and synthesis of that more efficient fluorescent probes which result in gaining increasing attention. Based on the versatile backbone of 1,1'-binaphthol, one new chiral fluorescent probe $S$-N1,N1'-(2,2'-dimethoxy-[1,1'-binaphthalene]-6,6'-diyl)bis (ethane-1,2-diamine) which may use to detect metal ion was synthesized in this article. It provides a new way of thinking and a certain foundation for the chiral binaphthol fluorescent probes study.

\section{Experimental Section}

Characterization: ${ }^{1} \mathrm{H}$ NMR and ${ }^{13} \mathrm{C}$ NMR spectra were collected on a Bruker AM-400WB spectrometer in chloroform-d as solvent and tetramethylsilane (TMS) as the internal standard. The mass spectra were obtained by using a Bruker Daltonics Autoflex II TOF system. Materials: $\mathrm{CH}_{3} \mathrm{I}$ (99.8\%, anhydrous), dimethyl sulfoxide (DMSO), $\mathrm{DCM}$ and $\mathrm{Br}_{2}$ were purchased from Aldrich. $\mathrm{Cu}$ (phen) $\mathrm{Cl}_{2}, \mathrm{Pd}(\mathrm{dppf}) \mathrm{Cl}_{2}, \mathrm{Na}_{2} \mathrm{~S}_{2} \mathrm{O}_{3}$, was purchased from J\&KCHEMICAL Co. All reagents and chemicals were purchased from commercial sources (Aldrich, Acros, and Guoyao) and used without further purification unless stated otherwise. All solvents were distilled over appropriate drying agent(s) prior to use and were purged with nitrogen. 


\section{Synthesis of (S) -6,6'-dibromo-[1,1'-binaphthalene]-2,2'-diol}<smiles>Oc1ccc2ccccc2c1-c1c(O)ccc2ccccc12</smiles><smiles>Oc1ccc2cc(Br)ccc2c1-c1c(O)ccc2cc(Br)ccc12</smiles>

Figure 1 the synthesis of $S$-6,6'-dibromo-[1,1'-binaphthalene]-2,2'-diol

To a solution of $S$-[1, 1'-binaphthalene]-2,2'-diol (2.86 g, $10 \mathrm{mmol})$ in DCM (50 mL) was added $\mathrm{Br}_{2}$ $(1.4 \mathrm{~mL}, 27.3 \mathrm{mmol})$ dropwise at $-78^{\circ} \mathrm{C}$. This mixture was stirred for3 hours. Then the reaction liquid natural at room temperature and continue stirred for 30 minutes, then add $\mathrm{Na}_{2} \mathrm{~S}_{2} \mathrm{O}_{3}$ saturated solution, stirred overnight. The organic layer was separated, and the aqueous phase was extracted with DCM three times, the organic phase was extracted with saturated brine 3 times and dried over $\mathrm{Na}_{2} \mathrm{SO}_{4}$, concentrated to the presence of a solid solution and then added a large number of petroleum ether, which was a large number of solid precipitation, filtered and washed with petroleum ether. Finally the white solid product was obtained $(3.85 \mathrm{~g}$, yield: $86 \%)$. ${ }^{1} \mathrm{H}$ NMR (400 $\left.\mathrm{MHz}, \mathrm{CDC1}_{3}, \mathrm{TMS}\right): \delta 8.20(\mathrm{~s}, 2 \mathrm{H}), 7.96(\mathrm{~d}, 2 \mathrm{H}, \mathrm{J}=8.0 \mathrm{~Hz}), 7.45-7.38(\mathrm{~m}, 4 \mathrm{H}) 6.94(\mathrm{~d}, 2 \mathrm{H}, \mathrm{J}=$ $8.0 \mathrm{~Hz}), 5.35(\mathrm{~s}, 2 \mathrm{H})$

\section{Synthesis of $S-6,6$ '-dibromo-2,2'-dimethoxy-1,1'-binaphthalene}
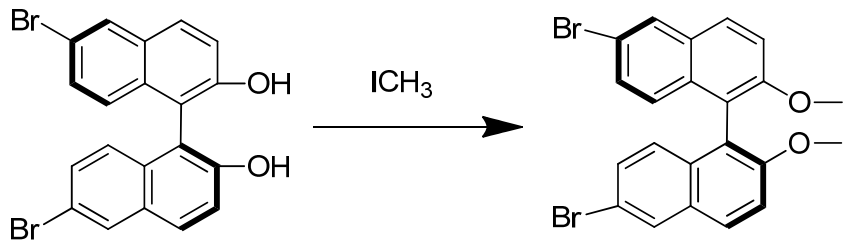

Figure 2 the synthesis of $S$-6,6'-dibromo-2,2'-dimethoxy-1,1'-binaphthalene

To a solution of $S$-[1,1'-binaphthalene]-2,2'-diol $(2.86 \mathrm{~g}, 10 \mathrm{mmol})$ in acetone $(15 \mathrm{~mL})$ was added $\mathrm{K}_{2} \mathrm{CO}_{3}(1.87 \mathrm{~g}, 13.5 \mathrm{mmol})$ and $\mathrm{CH}_{3} \mathrm{I}(1.68 \mathrm{~mL}, 27 \mathrm{mmol})$. The mixture was stirred and heated to reflux for 12 hours. The liquid was cooled to $25^{\circ} \mathrm{C}$ and then $\mathrm{CH}_{3} \mathrm{I}(0.8 \mathrm{~mL}, 12.9 \mathrm{mmol})$ and $\mathrm{H}_{2} \mathrm{O}$ $(7.5 \mathrm{~mL})$ was added to the solution. The reaction was stirred for 8 hour. Filtered and compound was washed with petroleum ether and water. After dried over $\mathrm{MgSO}_{4}$, light brown solid (1.79 g, yield: $84 \%$ ) was obtained. ${ }^{1} \mathrm{H}$ NMR (400 MHz, CDC1 13 , TMS): $\delta^{1} \mathrm{H}$ NMR (400 MHz, $\mathrm{CDC1}_{3}, \mathrm{TMS}$ ): $\delta$ $8.20(\mathrm{~s}, 2 \mathrm{H}), 7.96(\mathrm{~d}, 2 \mathrm{H}, \mathrm{J}=8.0 \mathrm{~Hz}), 7.45-7.38(\mathrm{~m}, 4 \mathrm{H}) 6.94(\mathrm{~d}, 2 \mathrm{H}, \mathrm{J}=8.0 \mathrm{~Hz}), \quad 3.86(\mathrm{~s}, 6 \mathrm{H})$.

\section{Synthesis \\ of \\ S-N1,N1'-(2,2'-dimethoxy-[1,1'-binaphthalene]-6,6'-diyl)bis}

(ethane-1,2-diamine)
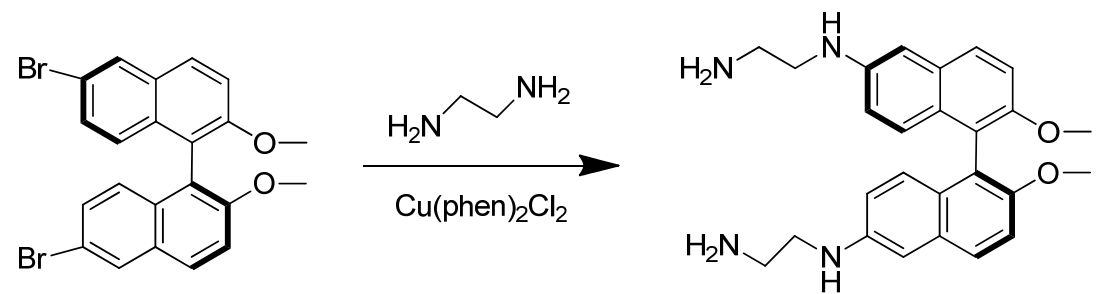

Figure 3 the synthesis of $S$-N1,N1'-(2,2'-dimethoxy-[1,1'-binaphthalene]-6,6'-diyl)bis (ethane-1,2-diamine)

To a solution of $\mathrm{CuCl}_{2}(5.6 \mathrm{mg}, 0.04 \mathrm{mmol})$ and $1,10-$ phenanthroline $(15.3 \mathrm{mg}, 0.08 \mathrm{mmol})$ and 1,10- phenanthroline $(15.3 \mathrm{mg}, 0.08 \mathrm{mmol})$ in DCM $(2 \mathrm{~mL})$. This mixture was stirred for 1 hour at $50{ }^{\circ} \mathrm{C}$. Then (S) -6,6'-dibromo-2,2'-dimethoxy-1,1'-binaphthalene (100mg, 0.2mmol) and $\mathrm{Pd}(\mathrm{dppf}) \mathrm{Cl}_{2}(30 \mathrm{mg}, 0.04 \mathrm{mmol})$ in DMF $(10 \mathrm{~mL})$ were added to the mixture. The reaction solution was heated to $120^{\circ} \mathrm{C}$ to clarify, then ethane-1,2-diamine $(2 \mathrm{~mL})$ was added. The mixture was stirred 
overnight. The organic phase was extracted with DCM and saturated brine. The combined organic layers were dried over $\mathrm{MgSO}_{4}$. The solvent was removed under vacuum, and the residue was purified by column chromatography on silica gel, finally yellow green solid product was obtained (25.1 mg yield: $27.5 \%) .{ }^{1} \mathrm{H}$ NMR (400 MHz, CDC13, TMS): $\delta 8.15(\mathrm{~s}, 2 \mathrm{H}), 7.72(\mathrm{~d}, \mathrm{~J}=8.9 \mathrm{~Hz}, 2 \mathrm{H})$, $7.34(\mathrm{~d}, \mathrm{~J}=9.0 \mathrm{~Hz}, 2 \mathrm{H}), 6.93(\mathrm{~d}, \mathrm{~J}=8.8 \mathrm{~Hz}, 2 \mathrm{H}), 6.85(\mathrm{~s}, 2 \mathrm{H}), 6.61(\mathrm{~d}, \mathrm{~J}=8.3 \mathrm{~Hz}, 2 \mathrm{H}), 5.96(\mathrm{~s}, 2 \mathrm{H})$, $5.30(\mathrm{~s}, 2 \mathrm{H}), 3.69(\mathrm{~s}, 6 \mathrm{H}), 3.57(\mathrm{~d}, \mathrm{~J}=5.4 \mathrm{~Hz}, 4 \mathrm{H}), 3.37(\mathrm{~s}, 4 \mathrm{H}) .{ }^{13} \mathrm{C} \mathrm{NMR}\left(101 \mathrm{MHz}, \mathrm{CDCl}_{3}\right) \delta$ 161.70 (s), 152.73 (s), 143.72 (s), 130.77 (s), 128.17 (s), 127.11 (s), 120.54 (s), 118.58 (s), 115.49 (s), $104.90(\mathrm{~s}), 57.29(\mathrm{~s}), 43.85(\mathrm{~s}), 37.70(\mathrm{~s})$.

\section{Summary}

We have developed an efficient method for the synthesis of binaphthyl derivatives bearing both $\mathrm{OH}$ functionalities (in the 2,2' and 6,6' positions of the aromatic skeleton). The key step was the coupling reaction by $\mathrm{Pd}(\mathrm{dppf}) \mathrm{Cl}_{2}$ to synthesis the $S$-N1,N1'-(2,2'-dimethoxy-[1,1'-binaphthalene]-6,6'-diyl)bis (ethane-1,2-diamine).

\section{Acknowledgement}

We are grateful for the financial support of the National Natural Science Foundation of China (No.21462018), the Science Fund of the Technology Office of Jiangxi, China (2009ZDS11100 and 20132BBE50024).

\section{References}

[1] Pu L. Fluorescence of Organic Molecules in Chiral Recognition. Chemical Reviews, 2004, 104: 1687-1716.

[2] Li S Y, Zheng QY, Chen CF et al., Fluorescent probes of d-(+)-gluconic acid $\delta$-lactone based on binary hosts of chiral calix [5] arene. Tetrahedron: Asymmetry, 2005, 16(16): 2816-2820.

[3] Tang LJ, Wang NN, Zhang Q et al., A new benzimidazole-based quinazoline derivative for highly selective sequenti recognition of $\mathrm{Cu}^{2+}$ and $\mathrm{CN}^{-}$. Tetrahedron Lett., 2013, 54, 536-540.

[4] Vulpe C, Levinson B, Whiteny S, et al., Isolation of a candidate gene for Menkes disease and evidence that it encodes a copper-transporting ATPase. Nat. Genet., 1993, 3, 7-13.

[5] Silva AP, Gunaratne HQN, Gunnlaugsson T et al., Signaling recognition events with fluorescent sensors and switches. Chemical reviews, 1997, 97 (5): 1515-1566.

[6] Silva AP, Mc Caughan B, Mc Kinney BOF et al., Newer optical-based molecular devices from older coordination chemistry. Dalton Transactions, 2003, 10 (1): 1902-191.

[7] Bissell RA, De Silva P, Gunaratne, HQN et al., "Moleeular fluorescent signaling with'fiuor-spacer-receptor'systems: approaches to sensing and switching devices via supramolecular photophysics". Chem. Soc. Rev., 1992, 21 (3): 187-195. .

[8] Tang LJ, Zhao J, Cai M et al., An efficient sensor for relay recognition of $\mathrm{Zn}^{2+}$ and $\mathrm{Cu}^{2+}$ through fluorescence 'off-on-off' functionality. Tetrahedron Letters, 2013, 54(45): 6105-6109.

[9] Chen $\mathrm{CH}$, Leung $\mathrm{M}$, The nature of 6, 6'-bis (triphenylamine) substituted BINOL as chromophoric and fluorogenic hybrid chemosensor for selective fluoride detection. Tetrahedron, 2011, 67(21): 3924-3935.

[10] Zhu BZ, Yuan F, Li RX et al., A highly selective colorimetric and ratiometric fluorescent chemodosimeter for imaging fluoride ions in living cells. Chem. Commun., 2011, 47, 7098-7110.

[11] Wang QG, Xie YS, Ding YB et al., Colorimetric fluoride sensors based on deprotonation ofpyrrole -hemiquinone compounds. Chem. Commun., 2010, 46, 3669-3671. 
[12] Huang WW, Lin H, Cai ZS et al., A novel anthracenebased receptor: Highly sensitive fluorescent and colorimetric receptor for fluoride. Talanta., 2010, 81, 967-971.

[13] Upadhyaya KK, Mishra RK, Kumara V et al., A coumarin based ICT probe for fluoride in aqueous medium with its real application. Talanta., 2010, 82, 312-318.

[14] Hu R, Feng J, Hu DH et al., A Rapid Aqueous Fluoride Ion Sensor with Dual Output Modes. Angew. Chem. Int. Ed., 2010, 49, 4915-4918.

[15] Tang L, Wang N, Guo J, Colorimetric and Fluorescent Recognition of Fluoride by a Binaphthol Thioureido Derivative. Bulletin of the Korean Chemical Society, 2012, 33(7): 2145-2148. 